\title{
Agnieszka Rydz
}

\section{Holograficzny model reminiscencji w poezji Czesława Miłosza}

\begin{abstract}
Rydz Agnieszka, Holograficzny model reminiscencji w poezji Czesława Miłosza [A holographic model of reminiscence in the poetry of Czesław Miłosz]. "Przestrzenie Teorii" 15. Poznań 2011, Adam Mickiewicz University Press, pp. 71-94. ISBN 978-83-232-2293-4. ISSN 1644-6763.

For a model of nostalgic memory in the poetry of Czesław Miłosz, based on the psychological phenomenon of reminiscence, an allegoric counterpart can be identified in the hologram metaphor (Douwe Draaisma). The question: "Who am I" - reappears in Miłosz's late lyrical poetry when he ponders over both his biography and the biographies of others. The response is provided, for instance, in the concept of human dialectic biography (of subject and object), formulated by Paul Ricoeur in his philosophical analyses. Human memory remains equally dialectic, placed in the antinomy between memory and oblivion. Still, retrieving a detail which has been remembered evokes all experience along with its rich context. That is the holographic effect, described in literature as the "ghost image". Also in poetry, the effacing of memory trace does not make a barrier for the restitution of recollection. "The Sun of Memory" beams through the lyric of the author of the collection of poems "This".
\end{abstract}

\section{Nostalgia i reminiscencja}

Wyjdźmy od osobistej refleksji Czesława Miłosza: „Kim jestem, kim byłem, / Nie tak już ważne” (W4, 159)1. Jednak wbrew powyższej konstatacji opracowywanie materiału osobistej przeszłości było ciągle żywym impulsem w działalności pisarskiej autora Światta dziennego. Taki stan rzeczy zostaje potwierdzony w jego ostatnich zbiorach poetyckich (od Kronik, 1987, po Wiersze ostatnie, 2006) praktyką obudowywania liryki licznymi autokomentarzami. Bo też rozważania, fragmenty notatek, roz-

${ }_{1}^{1}$ Skróty odsyłają do tytułów Czesława Miłosza z następujących edycji: Wiersze tom 4, przypisy A. Fiut, nota wydawcy J. Ilg, K. Kasperek, Wydawnictwo Znak, Kraków 2004; Wiersze tom 5, przypisy A. Fiut, nota wydawcy J. Ilg, K. Kasperek, A. Kosińska, które oznaczone zostają $\mathrm{w}$ tej pracy symbolami lokującymi teksty $\mathrm{w}$ poszczególnych tomach - odpowiednio: W4 albo W5. Inne skróty używane: DI - Dolina Issy, Wydawnictwo Literackie, Kraków 2000; PP - Piesek przydrożny, Wydawnictwo Znak, Kraków 1997; RE - Rodzinna Europa, Wydawnictwo Literackie, Kraków 1994; ZU - Ziemia Ulro, Instytut Literacki, Paryż 1977; ŻW - Życie na wyspach, Wydawnictwo Znak, Kraków 1997 oraz PŚ - R. Gorczyńska (E. Czarnecka), Podróżny świata. Rozmowy z Czestawem Miłoszem. Komentarze, Wydawnictwo Literackie, Kraków1992. Numer strony, z jakiej pochodzi cytat, podany zostaje w nawiasie po przytoczeniu. 
liczne, by tak rzec, Miłoszowskie „wypisy z ksiąg użytecznych” dopełniają jego lirykę o wspomnienia na temat przodków, przyjaciół, ujawniają też fascynacje lekturowe, ale i zdumienie nad biegiem własnego życia, czy szerzej filozoficznym bytem. Zrozumiałe w kontekście tożsamościowym pytanie: „kim jestem” - kanoniczna wątpliwość każdej formującej się świadomości powracała teraz przy okazji obrachunków z samym sobą, przeprowadzanych $\mathrm{w}$ dojrzałej fazie życia. Psychologia nazywa to zjawisko „efektem reminiscencji”. Mianem tym określa się swoiste uprzywilejowanie informacji pochodzących $\mathrm{z}$ przedziału czasowego między adolescencja a późnymi latami życia ${ }^{2}$. W literaturze przedmiotu wśród fenomenów mnemicznych wyodrębniony został też „efekt reminiscencji” (reminiscence bump), który:

sprawia, że osiągnąwszy pewien wiek $^{3}$, człowiek pamięta wydarzenia, które uczyniły go tym, kim jest obecnie. Podobieństwo między obecnym ,ja” a przeżyciami, które to ,ja” uformowały, w oczywisty sposób prowadzi skojarzenia starszej osoby do czasów jej młodości. Zgodnie z tą teorią, ludzie w podeszłym wieku, wracający myślami do przeszłości, pamiętają epizody, które stały się częścią ich historii życiowej. I na odwrót, sposób, w jaki opowiadają tę historię, określa i demonstruje ich własną tożsamośćc ${ }^{4}$.

Choć „wzniosłe tęsknoty” diagnozowane i eksplorowane w prozie przyzwyczaiły nas do analizowania „żywotów” bohaterów literackich u progu ich wejścia w wiek średni (Huelle, Kornhauser, Myśliwski), jednak pełnia talentów w tej materii ujawnia się dopiero w późnych latach życia, kiedy do głosu dochodzi specyficzna właściwość ludzkiej pamięci określana przez psychologów mianem „inteligencji narracyjnej”: „Jest to coś w rodzaju walki ze śmiercią i niepamięcią, to służba pamięci tego, co było"5. Warto przypomnieć, że impuls do rozwoju badań psychologicznych w obrębie specjalistycznych dziedzin dwudziestowiecznych nauk o człowieku popłynął z Bergsonowskiego rozróżnienia pamięci na dwa typy: wspomnienie i pamięć nawykową. Wyodrębnienie wspomnienia w auto-

2 Zob. T. Maruszewski, Pamięć autobiograficzna, Gdańskie Wydawnictwo Psychologiczne, Gdańsk 2005, [tu:] Pamięć autobiograficzna w wieku podeszłym, s. 148-169.

3 Wiek osób ulegających „efektowi reminiscencji” wedle ustaleń psychologów przypada na okolice sześćdziesiątego roku życia. Zob. D. Draaisma, Dlaczego życie płynie szybciej, gdy się starzejemy. O pamięci autobiograficznej, przeł. E. Jusewicz-Kalter, [tu:] Reminiscencje, s. 214-249. Autor podaje jako exemplum problemu autobiografię emerytowanego nauczyciela holenderskiego żyjącego w XIX stuleciu (tytuł: Rozważania na temat poważnego wieku lat sześćdziesięciu $w$ roku 1831; albo szkicowy zapis najosobliwszych zjawisk $w$ najwyżsym stopniu charakterystycznych dla tego wieku).

4 Tamże, s. 243.

5 Psychologowie określają początek tego procesu na sześćdziesiąty rok życia człowieka. Zob. więcej na temat: T. Maruszewski, Pamięć autobiograficzna, dz. cyt., s. 156. 
nomiczną domenę niosło następujące konsekwencje: uprzywilejowało pojęcie „śladu mnezyjnego"6, kluczowe dla eksplikacji problemu przedstawień, wiążąc go z procesem anamnezy i równocześnie dowartościowało poznawcze władze podmiotu, ponieważ: „Ślady zakładają świadomość, która te ślady interpretuje"7.

Paul Ricoeur, pisząc o Sobie samym jako innym, wykładał w skrupulatnej analizie wagę temporalności dla rozumienia siebie przez człowieka, pomijając wymiar przestrzenny egzystencji, uznajac, że to czynnik mniej przydatny dla określenia sensu ludzkiego istnienia. Zawarł tam również spostrzeżenie, które wydaje się szczególnie dogodne w sytuacji sędziwego Miłosza, że człowiek „poszukuje swej tożsamości właśnie na szczeblu całego życia"8, więc spoglądając na siebie przede wszystkim z uwzględnieniem perspektywy czasowej, z wysokiego dystansu minionych lat, by odszukać, jak to wyraził: „nieprzerwaną ciągłość w zmianie i w końcu trwałość w czasie, czyli to, co określa bycie tym samym"9.

Także Czesław Miłosz, w swojej późnej poezji, zagadnienia pamięci oraz świadomości podejmuje głównie $\mathrm{z}$ powodów tożsamościowych, bo namysł na temat „kim jestem”, w prostej linii wynika z intymnej opowieści, snutej o tym kimś, „kim było się w przeszłości”, a która - choćby z uwagi na specyficzną dialektykę pamięci - wcale nie musi wyłonić się z czeluści minionego czasu czytelna i kompletna. Wiele też czynników przemawia za tym, aby autora Dalszych okolic jako podmiot całościowej narracji autobiograficznej uznać za reprezentanta nowocześnie pojętej nostalgii ${ }^{10}$.

Toteż tempus, a nie locus w liryce Starego Poety okaże się literacką domeną wzniosłej nostalgii. Zjawisko to koresponduje z kryzysem ducho-

${ }^{6}$ Paul Ricoeur używa pojęcia w trzech znaczeniach: w postaci pierwotnego „śladu korowego” (neurologia), w formie „wzruszenia, uczucia utrwalonego w duszy” oraz jako „ślad zapisany w podłożu materialnym” („pismo”). Zob. P. Ricoeur, Pamięć, historia, zapomnienie, przeł. J. Margański, Universitas, Kraków 2006, s. 27.

7 D. Draaisma, Machina metafor. Historia pamięci, przeł. R. Pucek, Wydawnictwo Aletheia, Warszawa 2009, s. 192.

$8 \mathrm{P}$. Ricoeur, O sobie samym jako innym, przeł. B. Chełstowski, naukowo opracowała i wstępem poprzedziła M. Kowalska, Wydawnictwo Naukowe PWN, Warszawa 2003, s. 191.

9 Tamże, s. 202.

10 Analizę nowoczesnej nostalgii przynoszą książki: Przemysława Czaplińskiego, Wznioste tęsknoty. Nostalgie w prozie lat dziewięćdziesiątych, Wydawnictwo Literackie, Kraków 2001 i Marka Zaleskiego, Formy pamięci. O przedstawianiu przeszłości w polskiej literaturze wspótczesnej, Instytut Badań Literackich PAN, Wydawnictwo, Warszawa 1996. Natomiast problem epifanicznego światła w nostalgicznym oglądzie Litwy reaktywowanej przez Miłosza we wspomnieniu omawiam w: Miłosz i Świetlicki. Nostalgia versus melancholia. O pamięci autobiograficznej, [w:] Nowe dwudziestolecie (1989-2009). Rozpoznania. Hierarchie. Perspektywy, red. H. Gosk, Dom Wydawniczy ELIPSA, Warszawa 2010. 
wym przenikającym całe XX stulecie, a wychwyconym w przenikliwych diagnozach antropologicznych przez Simone Weil, Thomasa S. Eliota, Theodora W. Adorna i Czesława Miłosza, który przyswoił polszczyźnie dzieła pierwszych dwojga, przynosi próbę odpowiedzi na przemiany kulturowe dokonane w minionym wieku i - w refleksji autora Kronik - wiąże się tyle z porządkiem chronologicznym, ile przebiega w planie konsekwentnie przez niego konstruowanej autobiografii.

Dla modelu pamięci nostalgicznej w poezji Czesława Miłosza, opartej na zjawisku reminiscencji, ze względu na wielostronne dążenia autora do oddania pełni doświadczenia dostępnego istocie ludzkiej, można znaleźć egzystencjalny odpowiednik w metaforze hologramu (gr. holos, cały)11. Specyfika tego zapisu optycznego zasadza się na tworzeniu iluzji trójwymiarowości niemożliwej do uzyskania w płaskiej przestrzeni. Obecna $\mathrm{w}$ liryce Miłosza tendencja do poszerzania wymiaru doczesnego istnienia w zapisach epifanii poprzez łączenie wszystkich trzech aspektów temporalności (teraźniejszość, przeszłość i przyszłość jako repetycja zdarzenia $\mathrm{w}$ pamięci) pozostaje literackim ekwiwalentem konstytutywnych cech zjawiska holografii. Nieomal powtórzona z antycznego dramatu zasada jedności czasu fizykalnego we wspomnieniu wzbudzała niekiedy rozterki co do wyboru kształtu struktury narracyjnej: „Opowiadając, nie wie się, jaki wybrać czas, teraźniejszy czy przeszły, jakby to, co minęło, nie było całkiem minione, dopóki trwa w pamięci pokoleń - czy tylko jednego kronikarza" (DI, 13). Autobiograficzna opowieść, dodatkowo prześwietlona jasnym światłem, hojnym darem Mnemosyne, odbija istnienie niewyrażalnego, jakby to było „okno na rzeczywistość astralną zbudowaną ze światła, a nie z materii. Wrażenie jest czarodziejskie i urzekające"12, dzięki czemu pozwala metaforycznie uformować doświadczenie ludzkiej egzystencji w efektowną kulę, która odzwierciedla idee palingenezy w filozofii religii, utrzymując, iż możliwe jest odrodzenie duszy w następujących po sobie kołowrotach wcieleń („teoria wiecznych powrotów”).

Inną ważną cechą hologramu jest to, że na podstawie pojedynczej części daje się odtworzyć cały złożony obraz. Analogicznie, tzn. na przynależnościowej zasadzie pars pro toto, przełożone na behawioralny schemat: zmysłowy bodziec - reakcja pamięciowa, funkcjonują ślady mnezyjne w mechanizmie Miłoszowskiej reminiscencji nostalgicznej. Ponadto, cenną właściwością hologramu zostaje jeszcze to, że uszkodzenie jakiegoś fragmentu nie przekreśla in fine rekonstrukcji obrazu wizualnej całości. Możliwy jest wówczas efekt opisany w literaturze przedmiotu jako ghost

11 Por. D. Draaisma, Pamięć holograficzna, [w:] tegoż, Machina metafor..., dz. cyt., s. $253-282$.

12 Tamże, s. 253. 
image $^{13}$, kiedy wystarczy tylko cząstka obrazu, by wywołać jego pełnię wraz $\mathrm{z}$ towarzyszącym mu kontekstem zakodowanej informacji. W wierszu Czesława Miłosza fragment wspomnienia o kawiarni, w której przed wojną występowała znana pieśniarka, dał asumpt do tego, by ewokować całą jej postać: „Ruch taneczny, czerń jej włosów, biel jej skóry” (W4, 256), choć nie ma już dziś „Żadnego śladu po niej i tamtej kawiarni” (W4, 256). Konkluzja, pojawiająca się w zakończeniu tego utworu, zresztą utworu o znaczącym tytule Trwałość, wyrażona w stwierdzeniu: „I tylko cień jej ze mną, kruchość, piękno, zawsze" (W4, 256) oddaje po równi afirmację sił pamięci, co afirmację śladu „mnezyjnego”. Dlatego: „błogosławiony nich będzie dar / Wysnuwania opowieści z drobiazgu" (W4, 256).

Pamięć autobiograficzną cechuje ścisły związek z emocjami, których źródłem pozostają najczęściej kontakty z innymi ludźmi, szczególnie te o charakterze interakcji społecznych, istotne dla podmiotu memorialnego. Również nostalgiczna wrażliwość przejawia nierozerwalny związek z uczuciami, rzec by można, iż „karmi” się ona nimi do woli. Jakkolwiek nie każdy rodzaj emocji będzie odpowiednim tłem dla subtelnej zadumy nad minionym czasem. Nostalgia to prawdziwa kraina łagodności, do jakiej frenetyczne emocje, żywiołowe wybuchy złości ani nawet potoki rozżalonych łez, nie mają żadnego prawa dostępu. Bowiem najczęściej dziej się tak, że: „Nostalgia żywi się pamięcią, z której usunięto ból”14. Co najmniej od czasów Zygmunta Freuda rozmyślającego o zmiennych losach Wergiliańskiego herosa spod Troi, Eneasza, psychologowie wiedzą, że czar wspomnień przemienia oznaczenie emocjonalne smutnych zdarzeń z ujemnego na dodatnie ${ }^{15}$, co stanowi o autentycznej i modyfikującej pierwotne doznania sile sentymentów. W nostalgicznej relacji o wektorze kierunkowym: od dziś ku przeszłości, zostają zniesione i unieważnione wszelkie odniesienia do zdarzeń dawnych, o pesymistycznej barwie uczuciowej. Także Stary Poeta, snujący kiedyś rozważania o naturze wspomnień, zauważył w sobie jakieś „wielkie uspokojenie”16 i ten specyficzny stan wyciszenia emocji chciał również przypisać innym, jak on powracającym do osobistej przeszłości. Tedy, zabierając głos w imieniu zbiorowego „my” nostalgicznego, zdawał się optować za tym, aby i jego wyimaginowane audytorium poddało się oczyszczającemu umysł doświadczeniu

13 Zob. tamże, s. 260.

${ }^{14}$ M. Zaleski, Formy pamięci..., dz. cyt., s. 23.

15 Zob. T. Maruszewski, Pamięć autobiograficzna, dz. cyt. Również wypowiedź Czesława Miłosza potwierdza obserwacje psychologów oraz, co szczególnie cenne, dodatkowo otwiera refleksję na problemy poetyki, nie tylko psychologii twórczości: „Troska, zgryzota, wyrzuty sumienia, żal, wstyd, niepokój, przygnębienie - a z tego wysnuwa się poezja jasna, zwarta, lita, niemal klasyczna. I kto to może zrozumieć?” (PP, 102).

${ }^{16}$ Charakteryzując zjawisko epifanii, Miłosz powtarza za filozofem modernizmu Arturem Schopenhauerem, że ważny jest: „spokojny, uciszony stan umysłu artysty” (ŻW, 123). 
akceptowania minionego czasu. I chociaż stosunek do prywatnej przeszłości pozostaje sprawą nader skomplikowaną oraz intymną, a postawa akceptująca zakłada traktowanie rzeczy bardziej w kategoriach zamknięcia niż otwarcia, to Miłosz wskazywał na uwolnienie nowych perspektyw wyzwalających ludzkie patrzenie ze skazy uprzednich resentymentów:

przenosimy się w tamtą krainę minionego czasu, ale już bez ówczesnych naszych namiętności, do niczego już nie dążymy, niczego nie obawiamy się, stajemy się okiem, które ogląda i odnajduje szczegóły poprzednio wymykające się naszej uwadze $^{17}$

„Oko" wspomnienia zwolnione z przymusu podążania za dziejącymi się wydarzeniami, skoro wiadomy jest ich finał, może w całości skupić się nad tym, co „jest”, a dokładniej nad tym, co „było” i do woli delektować się smakiem okruszka wydobytym z magazynu pamięci, nim trafi na dobre do „spiżarni literackiej”. Pewne jest, że owo „wielkie uspokojenie” pozwoliło poecie patrzeć na minione łaskawszym okiem, wyrozumiale, a nawet „miłosiernie”, wybaczywszy innym oraz sobie winy z przeszłości i otaczając dawne żywoty czułością oglądu w rozproszonym i „miękkim” świetle osobistej nostalgii, gdy skonstatował, iż: „Przypomniane, krajobrazy i ludzkie postacie łagodnieją i pięknieją, przenika je szczególne światło [wyr. - A.R.], nawet dawny gniew zmienia się w litość i współczucie" (W4, 168). Również liryka Czesława Miłosza, czytana z perspektywy typowej dla nostalgii praktyki uśmierzania egzystencjalnego bólu, podlega oczywiście takim pamięciowym prawidłowościom, które raz, że płyną z realiów funkcjonowania ludzkiej psyche, a dwa, w odniesieniu do autora Światła dziennego, są konsekwencją obranej przez niego postawy wobec zdarzeń niesionych przez los, i - co trzeba mu sprawiedliwie przyznać - konsekwentnie wcielanej w dzieło, a także pochodną filozoficznego światopoglądu egzystencjalnego ${ }^{18}$. Stąd też odautorski podmiot jego poezji starannie usuwa z pola własnej uwagi myśli mogące zakłócić rozmyślnie projektowane przezeń wrażenie stałej i raczej niezmąconej pogody ducha albo wskrzeszać niegdysiejsze kompleksy, od których także i osobista biografia Miłosza nie była przecież wolna. Poeta, w swojej późnej

${ }^{17}$ Cyt. za: K. Van Heuckelom, „Patrzeć $w$ promień od ziemi odbity”. Wizualność $w$ poezji Czesława Miłosza, Instytut Badań Literackich PAN, Wydawnictwo, Warszawa 2004, s. 146.

$18 \mathrm{Tu}$ : postać Jeanne Hersch, przyjaciółki poety i zwolenniczki filozofii egzystencjalnej, od której autor Zniewolonego umysłu nauczył się wolności, jaką daje uwolnienie się od spraw przeszłych. Zob. Czego nauczyłem się od Jeanne Hersch?, gdzie w dwunastu punktach ujął Miłosz zasługi tej postaci dla jego pracy nad sobą i osobistego rozwoju. Ostatnia z odpowiedzi na pytanie tytułu może stanowić podsumowanie tego wątku rozważań: „Że we własnym życiu nie wolno poddawać się rozpaczy z powodu naszych błędów i grzechów, ponieważ przeszłość nie jest zamknięta i otrzymuje sens nadany jej przez nasze późniejsze czyny" (W5, 130). 
twórczości stanowczo zaznaczał, iż są to dawne sprawy, już zamknięte i pozostające bez jakiegokolwiek wpływu na jego zrównoważoną emocjonalnie kondycję w sędziwym wieku. Zapis Miłosza pod tytułem Obudzony, zamieszczony $\mathrm{w}$ formie autokomentarza do liryków zebranych w tomie wierszy To (2000), rejestruje stan takiego wyciszenia umysłu i równowagi uczuć. Dzięki świadomości dobrze przeżytego życia w osobistej konfesji wypowiadał słowa pełne akceptacji dla ziemskiej destynacji człowieka:

Spokój, który czułem, był spokojem zamknięcia rachunków i łączył się z myślą o śmierci. Szczęście po tej stronie było niby zapowiedź tego samego po drugiej stronie. Zdawałem sobie sprawę, że otrzymuję dar nieoczekiwany i nie mogłem pojąć, dlaczego spadła na mnie taka łaska (W5, 112).

Rachunek elegijny skłaniał też do podjęcia tematu losu artysty. $\mathrm{W}$ nader szczerym wierszu, poruszającym kwestie indywidualnych upodobań i gustów literackich oraz duchowych inspiracji (Mnie zawsze podobat się), w końcówce życia, ujawniał autor Hymnu o perle własne rozumienie powinności obowiązujących poetę:

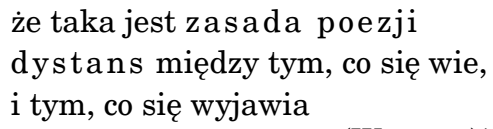

$(\mathrm{W} 5,226)^{19}$

W takiej metodzie postępowania przejawia się owa słynna „poetyka zdystansowanego widzenia” 20 i jeszcze „coś”, co wykracza dalece poza aksjologiczne ramy twórczej praxis dojrzałego artysty - mądrość Starego Poety. Dlatego słowa przekazywane czytelnikom za pośrednictwem wierszowanej strofy są po trosze testamentem, a po części rodzajem apelu, kierowane, by te kwestie przemyśleć z samym sobą:

Ten mały park, zielonawe popiersia z marmuru

W świetle perłowym, w letni drobny deszcz

Niech jak był, kiedy pchnęliście furtkę, zostanie. [wyr. - A.R.]

I ulica wysokich zliszajonych bram,

Którą ta wasza miłość przemieniła

(W4, 14).

19 Por. inne liryki Czesława Miłosza podejmujące ten temat, m.in.: Przepis, To jasne, Przeciwko poezji Filipa Larkina. Nieużalanie się nad sobą jest dla tego poety kwestią stylu, dobrego smaku. Charakterystyczna dla tej powściągliwej postawy pozostaje również wypowiedź na temat pisarstwa autorki Nad Niemnem: „O Orzeszkowej myślę zawsze z miłością i szacunkiem, jest ona dla mnie przykładem pisarza w służbie dobra. Na pewno wiedziała więcej o mrocznych stronach ludzkiej egzystencji, ale wolała, ze względów, które uważała za wyższe, tej swojej wiedzy nie ujawniać” (W5, 42).

20 Zob. J. Zach, Miłosz i poetyka wyznania, Universitas, Kraków 2002. 
Każdy, podobnie do poety, obdarzony został przecież zdolnością świadomego kształtowania treści intymnych wspomnień. Toteż tylko od indywidualnej świadomości podmiotu zależy interpretacja zdarzeń płynących $\mathrm{z}$ zapisu osobistej przeszłości. Na podstawie tego drobnego fragmentu można odczytać intencję poety, który proponuje, aby zdeponowane w pamięci widoki charakteryzowały się $\mathrm{w}$ memorialnym uobecnieniu maksymalnie mimetyczną wiernością szczegółów. Zdawałoby się, że nieomal opowiada się tu Miłosz za naturalistycznym weryzmem. Dlatego park ma być, jaki był - z marmurem posągów, prowadzącą do niego furtką i ulicą, zapamiętany w budzącej zachwyt aurze, „w świetle perłowym”. Nasuwa się w tym miejscu pytanie: gdzież jest więc miejsce dla osobliwej optyki artystycznej, z jej autonomicznym i subiektywnym oglądem rzeczywistości oraz prawem kreacji? Ale, powyższa cząstka należy do utworu pod wiele sugerującym tytułem - Po wygnaniu, który, o ile można tak powiedzieć, na sposób podręcznikowy ilustruje stan rzeczy, w jakim o mocy lirycznego widzenia decydują nie tyle zasady nowocześnie pojmowanej poetyki, ile psychologiczna i zarazem pamięciowa tendencja do uładzania poszarpanych brzegów istnienia oraz do „cukrowania” zapamiętanej przeszłości. Dobrze widać tę prawidłowość w zjawisku nostalgii za PRL-em, w powieściach napisanych po 1989 roku, a fakt ów Przemysław Czapliński skomentował następująco:

źródeł sentymentu należy szukać w mechanizmie nostalgii, który pozbawia historię ciągłości i aksjologicznej obiektywności, wyjmując zdarzenia z kontekstu i postępując z nimi według praw serca [wyr. - A.R.], a nie rozumu. Dlatego jest tyle historii, ile wspomnieńn ${ }^{21}$.

Utwór Miłosza, i oczywiście nie tylko ten jeden wybrany przeze mnie i do tego zacytowany w krótkim fragmencie, został oczywiście skomponowany ze słów będących szczodrą „mową serca”. Jednak w przypadku osobistej reminiscencji jest to zwyczajna sytuacja. Dokładniej formułując ten wniosek, przyjdzie jeszcze stwierdzić, że choć obraz zdarzenia będzie wiernie zakodowany przez pamięć podmiotu, bo dosłownie w kształcie: ,jaki był”, zostanie powierzony memorii, ale o nadaniu mu sensu każdorazowo decyduje sam uczestnik życiowej sytuacji. Emocjonalna wartość reprezentacji może pochodzić wyłącznie od świadomej aktywności człowieka interpretatora egzystencjalnych zdarzeń. Nie ma jednak żadnych podstaw, aby uważać, że w jakimkolwiek punkcie swej twórczości autor Drugiej przestrzeni nakłaniał do celowego zafałszowywania wspomnień. To nie o to chodzi, żeby brzydkie pod względem estetycznym realia ludzkiego bytowania, czego znakiem sa w wierszu „liszaje” pokrywające bramy ulic, zamieniać $\mathrm{w}$ pamięci na gładkie i wypolerowane powierzchnie

21 P. Czapliński, Wznioste tęsknoty..., dz. cyt., s. 27. 
subiektywnych iluzji. Miłosz raczej zaleca, by te mizerne składniki, oszpecające codzienną egzystencję, zaakceptować w ich ułomnej i dalekiej od doskonałości formie. Dokona się wówczas „miłosna przemiana” rzeczywistości pod jednym, acz niezbywalnym warunkiem - istnienia uczuciowego związku $\mathrm{z}$ obiektem powierzanym pamięciowej admiracji. Konieczne będzie też, aby ta rzecz pochodziła ze świata, z którym można się bez przeszkód zidentyfikować, innymi słowy, aby płynęła ona z na wskroś intymnego „światoodczucia” (Heidegger).

\section{Blask i ciemność}

Nie znaczy to jednak, że wewnętrzna ocena wydarzeń biograficznych dokonana przez Miłosza stale podlegała regulacji przez nieodmiennie łagodny przepływ fal nostalgii. Doświadczenie śmierci najbliższych osób burzyło, zdawałoby się, niewzruszony ład myśli mędrca, targając sprzecznymi uczuciami i zmuszało do nagłego urwania wątku kojącego ciepła wspomnień. Predylekcja autora Doliny Issy do fascynacji przemijalnością, jako rzecz znana, zwalnia jakoby z obowiązku wprowadzenia objaśniającego komentarza, ale warto przy tej okazji odnotować wybór tematu maturalnego przez przyszłego pisarza i poetę. Wypowiedź o heraklitejskiej rzece czasu, z uwagi na młody wiek autora, może zaskakiwać, lecz nie wtedy gdy, jak gimnazjalista Miłosz, uległo się wcześnie fascynacji Wyznaniami św. Augustyna. Wiadomo, że biskup Hippony ${ }^{22}$, zanim znalazł uspokojenie gwałtownych myśli oraz czynów w wierze chrześcijańskiej, gorączkowo poszukiwał prawdy o ludzkiej kondycji naznaczonej sprzecznościami, które żywo go dotykały, wręcz raniły, lecz ani gorliwe studia nad Platonem, ani przystąpienie do sekty manichejczyków oraz zgłębianie ich doktryny pod okiem uczonego Faustusa nie przyniosły mu więcej nad rozczarowania i poznawczy zawód, czemu dał wyraz, wypowiadając słowa: Amicus Plato, sed magis amica veritas...

Jednym z najbardziej „manichejskich” tekstów Czesława Miłosza jest tren żałobny Na pożegnanie mojej żony Janiny, z tomu Kroniki (1987), w którym poeta niejako odtwarza poznawczą drogę średniowiecznego filozofa. Filarem, na jakim wspierał się manichejsko urządzony świat, był nieprzezwyciężalny dualizm światła i ciemności, konotujący cały szereg

22 Nie bez znaczenia dla nawrócenia późniejszego świętego miały też doświadczenia mistyczne samego Augustyna (tzw. medytacja mediolańska) i jego matki Moniki, również świętej Kościoła rzymskokatolickiego oraz dogłębne przeżycie przez niego śmierci matki i syna Adeodata, co prawdopodobnie przesądziło o przyjęciu chrztu, a potem święceń kapłańskich przez niegdysiejszego grzesznika dźwigającego się $\mathrm{z}$ „dna upadku” moralnego. Zob. Św. Augustyn, Wyznania, przeł. oraz wstępem i kalendarium opatrzył Z. Kubiak, Wydawnictwo Znak, Kraków 2007. 
wartości w porządku symbolicznej interpretacji rzeczywistości przez człowieka. Także ludzki los, odczytywany przez pryzmat manicheizmu, znajduje wizualny odpowiednik w liryce Miłosza w motywie areny albo sceny, często spotykanych, szczególnie w zbiorach wierszy To czy Druga przestrzeń, gdzie przybierają one groźną postać kosmicznego „dziwowiska”, napawającego egzystencję człowieka autentycznym „lękiem i trwogą". Jedyny oręż w nierównej walce, jaką istota ludzka prowadzi z potężną Naturą skazującą jej byt na nieistnienie, stanowią efektowne i teatralne „stroje, maski, koturny” (W5, 131). Sposób zaś reżyserowania spektakli na scenie tegoż metafizycznego theatrum przez Miłosza skłonił nawet Jarosława Płuciennika do zaklasyfikowania utworów realizujących ten model Dasien przez istotę ludzką, do przykładów Lyotardowskiego pojmowania wzniosłości23. Sam poeta, niechętny był kategorii ponowoczesności, ale uwzględniwszy jego autokomentarze, wolno przypuszczać, że raczej przystałby na filozoficzne konstatacje wywiedzione z pism egzystencjalistów francuskich ${ }^{24}$.

Doświadczenie graniczne pustki w spotkaniu z nicością przypadło w udziale Obcemu bohaterowi Alberta Camusa, podczas czuwania nad trumną matki, w nieznośnym upale afrykańskiego Algieru oraz w serii wydarzeń fabularnych (przypadkowe zabójstwo Araba na plaży, proces, egzekucja) roznieconych przez ten kluczowy dla rozumienia jego historii biograficzny epizod. Wszystko odbyło się przecież w oślepieniu przez słońce, gdy można w sposób krańcowy odczuć własną obcość w świecie. Mówi o tym poniższy fragment monologu bohatera: „Dzisiaj przelewające się słońce wprawiło ten pejzaż w drżenie, czyniąc go nieludzkim i przygnębiającym"25, w którym to urywku przyrodniczy krajobraz jest czytelnym ekwiwalentem wyostrzonej krańcowo świadomości postaci.

Natomiast w pożegnalnym liryku Miłosza widok świata zostanie całkowicie przesłonięty przez blask i żar, bijące od pałającego ognia w czasie ceremonii kremacji ciała zmarłej żony. W wyobraźni poety ten żywioł asocjuje w obraz rozlewającej się rzeki ognia, na podobieństwo jakiegoś apokaliptycznego potopu, będącego rezultatem niszczycielskich działań „Heraklita szalonego” (W4, 157). Pozostały we władaniu ognia poeta bezradnie patrzył, jak zachłanny płomień konsekwentnie i nieodwołalnie trawił fundamenty jego świata, rozumianego najprościej, w postaci zniszczenia wspólnoty zawiązanej w sakramencie małżeństwa, gdy dwoje zo-

${ }^{23}$ Zob. J. Płuciennik, Figury niewyobrażalnego. Notatki z poetyki wzniosłości $w$ literaturze polskiej, Universitas, Kraków 2002.

${ }_{24} \mathrm{Z}$ tym drobnym zastrzeżeniem, że nie byłby to na pewno egzystencjalny projekt Jeana Paula Sarte’a, zbyt pesymistyczny i zogniskowany na doznaniu otchłannej nicości przez człowieka.

25 A. Camus, Obcy, przeł. M. Zenowicz, PIW, Warszawa 1995, s. 15. 
stają „Złączeni przysięgą na złe i dobre” (W4, 157). Toteż, w kontekście uświęconych słów tekstu przysięgi zupełnie było to dla niego niezrozumiałe, że w konfrontacji z nicością musi mierzyć się z przerastającym go doświadczeniem sam, bez kobiety, która mu ślubowała, a on jej. Wobec owej nicości, nad urną z prochami żony, popadł w stan obezwładniającej asymbolii ${ }^{26}$, niezdolny, by móc odczytać tradycyjną mowę ognia, „Do którego języki ludzkie porównują miłość" (W4, 157), bo jemu nie było wtedy ani „do języków”, „ani do modlitwy”. Odrętwienie nie ustępowało, ponieważ, jak powiada filozof odczytujący myśl Fryderyka Nietzschego, śmierć zawsze wymyka się pojęciom:

Śmierć nie jest „czymś”, co można zrozumieć. Śmierć to unicestwienie wszelkich warunków zrozumienia, dzięki którym możemy coś pomyśleć, także siebie samych. Tym samym perspektywa śmierci usuwa nam grunt spod nóg, podważa wszelkie możliwe oparcie, zabiera szansę na ławkę, na pewność, na spokój. Śmierć odsłania kres wszystkich pojęć - a więc jest niepojmowalna ${ }^{27}$.

Ale wytrwałe wpatrywanie się $\mathrm{w}$ taniec płomieni może doprowadzić do stanu, kiedy te specyficzne ,języki” przemówią w końcu także do sensualnej wrażliwości człowieka, dzięki czemu wróci mu mowa i możliwe będzie wypowiedzenie miłosnego wyznania:

\section{Kochałem ją, nie wiedząc, kim była naprawdę. Zadawałem jej ból, goniąc za moją ułudą. \\ Zdradzałem ją z kobietami, jej jedynej wierny. \\ Zaznaliśmy wiele szczęścia i wiele nieszczęścia,}

(W4, 157).

Zobaczmy, że bohater liryczny: „kochał, ale - nie znał”, „mimowolnie zadawał prawdziwy ból - ale podążał za fantazmatem”, „zdradzał, ale był wierny". Słowa te świadczą o kompleksie winy, ponieważ nie był dość uważny. Poza tym, każde z wypowiadanych zdań staje się rodzajem egzystencjalnego paradoksu, a zestawione $\mathrm{w}$ dwie kolumny słowa $\mathrm{z}$ nagłosu i klauzulowej przestrzeni wersów w tym fragmencie pogłębiają jeszcze spiętrzenie dostrzeganych sprzeczności:

$\begin{array}{ll}\text { kochałem } & \text { prawda } \\ \text { zadawałem (ból) } & \text { ułuda } \\ \text { zdradzałem } & \text { wierność } \\ \text { zaznałem (szczęścia) } & \text { nieszczęście }\end{array}$

${ }^{26}$ Termin oznacza reakcję podmiotu na utratę obiektu „semiotycznego” (tj. związanego z biologicznym istnieniem). Zob. J. Kristeva, Czarne stonce. Depresja i melancholia, przeł. M.P. Markowski, R. Ryziński, wstęp M.P. Markowski, Universitas, Kraków 2007.

27 K. Michalski, Płomień wieczności. Eseje o myślach Fryderyka Nietzschego, Wydawnictwo Znak, Kraków 2007, s. 124. 
Jeśliby, dodatkowo, połączyć nagłosowe wyrazy w pary, to uzyskane w ten sposób dublety: „kochałem - zadawałem ból”, „zdradzałem - zaznałem szczęścia”, kwestionują wzajemnie swoją wymowę, znosząc sens trwałości miłosnego uczucia, unieważniając jednocześnie pojęciową dystynkcję w sąsiadujących parach rzeczowników z klauzuli: „prawda - ułuda”, „wierność - nieszczęście”. Dualistyczne frazy, nasycone „sekretnymi manichejskimi truciznami", przenikają do świadomości podmiotu oraz ukazują jego miłość w sposób z pozoru relatywny. I tylko wyobraźnia poety łączy w jedno siły przeciwstawnych żywiołów, wyrażając tym samym stałość uczucia i niezmienność słownych deklaracji sprzed lat. Ogień i woda, ta antynomiczna para funkcjonuje w ludowym porzekadle jako symbol niemożliwego, w przestrodze mówiącej o tym, że nigdy nie da się „pożenić wody z ogniem”, ale twórcza imaginacja artysty podąża sobie tylko znanym szlakiem i porzuca powszechnie doświadczane życie w niepodległej drodze ku niewyobrażalnemu. W kolejnej wizji, w której unieważnione zostaną prawa fizyki Izaaka Newtona, gdy planeta wyzwala się spod działania sił grawitacji: „Jabłko nie spada na ziemię. / Góra porusza się z miejsca" (W4, 157), zza kurtyny ognia wyłoni się w końcu wiersza obraz odnowionego świata. Ogień jest tu warunkiem apokatastasis. Są to pogłosy "teorii transmutacji” sformułowanej przez krewnego poety Oskara Miłosza28, przeświadczonego, iż możliwe jest przekształcenie materialnego lux, czyli fizykalnego światła w boskie, a co za tym idzie wieczne lumen. Również Simone Weil poświęciła wiele uwagi symbolice oczyszczającego ognia, czynnika w soterycznej koncepcji jej autorstwa, upatrując w nim nie żywiołu zniszczenia, ale głównego środka ocalenia ziemskich bytów, które przenikają do wieczności w postaci świetlistych esencji, po oczyszczeniu ich z ludzkich skaz i ułomności. Poza tym, w wyobrażeniach francuskiej autorki rola czyśćcowego żywiołu nie wyczerpuje się na tym działaniu. Pełni on też funkcję specyficznego łącznika między ziemską i pozaziemską rzeczywistością. W funeralnym wierszu Miłosza można odnaleźć wszystkie te wątki rozważań mistyków. Ogień, kumulujący w sobie soteryczne sensy w tym na poły manichejskim, na poły mistycznym trenie żałobnym, niespodziewanie dostarcza też odpowiedzi na pytanie:

Jak bronić się przeciw nicości? Jaka moc

Przechowuje, co było, jeżeli nie trwa pamięć?

(W4, 157).

Powtórzmy więc, że odpowiedzi udzieli ogień. W analizie znaczeń heraklitejskiej rzeki czasu, metafory łączonej zwykle z symboliką przemija-

28 Analizy znaczenia motywu światła w poezji Miłosza podejmuje się Kris Van Heuckelom w książce: „Patrzeć w promień...”, dz. cyt. 
nia, Krzysztof Michalski wskaże na jej antytetyczne sensy w serii przekształceń: w „rzekę ognia” (Heraklit), „pożar świata” (ojcowie Kościoła), „metaforę wiatru” (Nietzsche), a na koniec właśnie w „metaforę ognia” (Hegel) rozumianego jako synonim wiecznego trwania:

Ogień, o którym tu wszędzie mowa, jest sprawdzianem, miarą naszego życia; oddziela to, co upodabnia nas do Boga i co w związku z tym, jest w nas trwałe, co jest wieczne, czego ogień nie zniszczy (złoto, srebro, drogie kamienie) - od całej reszty, podlejszego pochodzenia (drzewo, siano, słoma, miedź, cyna i ołów, ciernie i oset), skazanej na pastwę płomieni ${ }^{29}$.

Sui generis ogniem pozostaje również ludzka pamięć, zdolna, by rozbłysnąć jasnym płomieniem wspomnienia.

„Wielka miłość czyni wielką żałość” (W4, 267), te słowa anonimowej skargi, wykorzystane wcześniej w formie motta do utworu Dawno $i$ daleko, mogłyby także poprzedzać poemat Czesława Miłosza pt. Orfeusz $i$ Eurydyka z 2002 roku, napisany in memoriam Carol, drugiej żony poety. Trafna wydaje się konstatacja Ewy Bieńkowskiej, która interpretując owe „poema” o funeralnym charakterze, uznała, że ten wyjątkowy w dorobku poety utwór nie należy do „ćwiczeń stylistycznych” ani nie jest też powodowany chęcią sprawdzenia własnych sił poetyckich przez podjęcie tematu o szacownym rodowodzie antycznym ${ }^{30}$. Wynika natomiast z mierzenia się z rzeczą dla człowieka najtrudniejszą, z pustką ziejącą po śmierci ukochanej osoby, odwzajemniającej uczucie miłości: „Bowiem temat ma to do siebie, że każdy śmiertelnik powtarza go w swoim imieniu, przeżywa los jego bohaterów" 31 . Dlatego wywiera wstrząsające wrażenie na odbiorcy, nawet gdy ten nie łączy go z osobistym wydarzeniem z biografii Miłosza.

Doświadczenie zstąpienia do otchłani po ukochaną Eurydykę, by przywrócić ją światu żywych, zostało $\mathrm{w}$ niniejszym poemacie oddane w nowoczesnym przedstawieniu mitycznego Hadesu, w ujęciu go za pośrednictwem wielkomiejskich realiów. Tym samym został oddany rys melancholii nowoczesnej, wybierającej pejzaż metropolis ${ }^{32}$ za tło, z którego utrata wycina się bolesnym kontrastem konturu obramowanej w ten sposób pustki. Tutaj Hades pokazany jako system korytarzy i wind stanowi zmyślny labirynt, na straży którego czuwają przerażające „elektroniczne psy”, poruszające się bez najmniejszego szmeru, zupełnie bezsze-

${ }^{29}$ K. Michalski, Esej VII: Płomień wieczności, w: tegoż, Płomień wieczności..., dz. cyt., s. 162.

30 Zob. E. Bieńkowska, W ogrodzie ziemskim. Książka o Miłoszu, Wydawnictwo Sic!, Warszawa 2004, s. 262.

31 Tamże.

32 Por. M. Bieńczyk, Przezroczystość, Wydawnictwo Znak, Kraków 2007. 
lestnie. Do tego, by tam wejść, mogła skłonić bohatera tylko „uczłowieczająca” jego „zimne serce poety”33 miłość Eurydyki oraz zapamiętane jej słowa: „Jesteś dobrym człowiekiem” (W5, 271), które niosły go po krętych drogach świata podziemi. Ale i tak:

Marzł. Miał świadomość, że znalazł się w Nigdzie [wyr. - A.R.]

Pod tysiącami zastygłych stuleci,

$\mathrm{Na}$ grochowisku zetlałych pokolen,

To królestwo zdawało się nie mieć dna ni kresu

(W5, 271).

W miejscu, które nazwał „Nigdzie”, jego pieśń wprawiająca żywych w ekstazę, pieśń chwaląca ulotną urodę ziemskich rzeczy: „różany brzask”, „lot ptaków”, „smak wina”, „zapach naręczy bzu” i kolory: „cynobru, karminu, sieny palonej, błękitu”, przed ametystowym i żałobnym tronem Prozerpiny, znaczyła tyle, co „nic”. A on sam mógłby w tej nieczułej i obojętnej na jego wdzięk krainie nosić imię „Nikt”, gdyby nie został wcześniej nazwany mianem „Orfeusza”, i było to naprawdę najlepsze imię dla kogoś tak osieroconego jak on ${ }^{34}$.

Kontakt z nicością wymusił na Ja „doznającym” osobistą utratę, nowy modus zachowania, naznaczając go sprzecznością i opozycyjny do wcześniejszego wzorca życiowego doświadczenia, ale pasujący do swoistego decorum, jakie podyktowane zostało teraz przez ,żywot $\mathrm{w}$ sobie sprzeczny”: „Nie umiejący płakać, płakał nad utratą” (W5, 273), „Wiedział, że musi wierzyć i nie umiał wierzyć" (W5, 273). Jednak istotne, że nieodmienione zostało $\mathrm{w}$ nim to, co najważniejsze: „że swoje słowa układał przeciw śmierci” [wyr. - A.R.]. Miłosza bunt „przeciw śmierci" koresponduje ze stanowiskiem Emmanuela Levinasa, który podjąwszy krytykę Heideggerowskiej koncepcji „bytu-ku-śmierci” zaznaczał, że ludzki byt realizuje się zawsze nie „ku”, lecz „przeciwko” kresowi kładącemu koniec ziemskiej egzystencji człowieka ${ }^{35}$. Toteż, aby wyrazić tę wspólną prawdę, wywiedzioną z lektur współczesnych filozofów i dawnych aojdów starożytnego świata, w poemacie Miłosza Orfeusz musi zostać dosłownie „wypluty” przez otchłań, a doznanie jej obcości musi być dla niego odstrę-

${ }^{33}$ Por. utwór Zbigniewa Herberta Apollo i Marsjasz, gdzie występuje motyw nieludzkiej doskonałości artysty.

${ }^{34} \mathrm{~W}$ starej grece, o czym przypomina Zygmunt Kubiak w eksplikacji etymologii imienia prototypu bohatera w mitologii, istniały dwa rdzenie: orphanos - „sierocy”, który przetrwał do dziś w zbliżonej formie w angielskim w wyrazie orphan, „sierota” oraz orphne - „ciemność nocy”, sama „noc”. Zob. Z. Kubiak, Mitologia Greków i Rzymian, Świat Książki, Warszawa 1998, s. 354.

35 Przypomina o tym Paul Ricoeur, przytaczający poglądy Emmanuela Levinasa w swojej polemice z Martinem Heideggerem. Zob. P. Ricoeur, Pamięć, historia..., dz. cyt., s. 480 . 
czające, i po doświadczeniu tej nicości sam - mówiąc językiem Paula Ricoeura - musi „żyć $a \dot{z} d o$ ”. Inaczej rozumie sens zakończenia tego poematu Bieńkowska notująca uwagę:

Po raz pierwszy może w poezji Miłosza magia świata jest obezwładniona przez doświadczenie nieszczęścia, które kiedyś magia ta równoważyła, wiążąc jednostkę z życiem więzią silniejszą niż śmierć36.

Trudno zgodzić się z tym stanowiskiem bez zastrzeżeń. Istotnie, skala porażenia nieszczęściem nie znajduje odpowiednika w całej twórczości autora Drugiej przestrzeni. Jednak ekspresja rozdzierającego krzyku Orfeusza przyzywającego obecności Eurydyki zostaje, moim zdaniem, zrównoważona dwoma wersami zamykającymi poemat. Można uznać je za pointę utworu, wskazującą przy tym na dokonujący się powrót bohatera z nicości do życia:

Ale pachniały zioła, trwał nisko brzęk pszczół.

I zasnął, z policzkiem na rozgrzanej ziemi

(W5, 274).

A więc sen wcale nie musi być koszmarem, powtórzeniem traumy śmierci, przeciwnie - może przynosić ukojenie Ja „przeżywającemu”, tutaj melancholijnie zawieszonemu na krawędzi między bytem i niebytem. Zwłaszcza taki sen, gdy policzek śniącego bezpośrednio dotyka ciepłej ziemi, ogrzanej przez słońce, przez co znów związek egzystencji człowieka z tellurycznym podłożem zostaje wzmocniony, a powrót do świata żywych uzyska ostateczne potwierdzenie. Pamięć podpowiada $\mathrm{w}$ tym miejscu Miłoszowskie „kadry” z rzeczywistości, utrwalające radosny widok: kolibrów nad kwiatami kapryfolium, pszczoły krążącej nad nasturcją, tych czytelnych obrazów ziemskiej idylli albo samych wyobrażeń rajskiego ogrodu w świetlistych pejzażach Drugiej przestrzeni, niosących człowiekowi eschatologiczne pocieszenie.

W obu utworach pisanych przez Czesława Miłosza z intencją in memoriam: Na pożegnanie mojej żony Janiny oraz w Orfeuszu $i$ Eurydyce uderza absolutny brak jakiegokolwiek osobistego szczegółu wiązanego z obecnością zmarłych żon. Żadnych tu śladów choćby szminki, pudru, sukni - rekwizytów pozwalających domyślić się, czy zgoła potwierdzić obecność kobiety, jak to ma miejsce w realiach innych utworów lirycznych jego pióra. A przecież autor zbioru poezji pt. To dawał niejednokrotnie wyraz przekonaniu, że cokolwiek, na przykład błahy detal w rodzaju: „pamiątki, znaku, czegoś, / co nie ginie” (W4, 268), wystarczy mu, aby

${ }^{36}$ E. Bieńkowska, W ogrodzie ziemskim..., dz. cyt., s. 264. 
mógł zarzucić kotwicę pamięci ${ }^{37}$. Sytuacja ta wydaje się też osobliwa w świetle tradycji gatunkowej trenu. W pierwowzorze Jana Kochanowskiego po zmarłym dziecku pozostały „żałosne ubiory”, potęgujące rozpacz ojca. Różnica wynika tu jednak z odmiennej motywacji przyświecającej dwudziestowiecznemu poecie. Bowiem differentia specifica obu wypowiedzi żałobnych Miłosza wskazuje, że wśród jego twórczości lirycznej o charakterze nostalgicznym należy oddzielić utwory - przedstawienia „pracy pamięci", bazujące na istnieniu śladu mnezyjnego, który w procesie anamnezy bądź samorzutnie objawionej epifanii naprowadza na wspomnienie osoby czy zdarzenia, od liryków z wyraźnie wyeksponowaną funkcją sensu stricto memorialną, które mają przede wszystkim upamiętniać. Wówczas wierność „życio-podobnym” realiom przeszłości, jako kwestia mniej znacząca, zostaje usunięta z pola świadomości podmiotu w cień, na marginesy uwagi.

$\mathrm{Na}$ podstawie ostatnich esejów Paula Ricoeura, opublikowanych we fragmentach, których niestety filozof nie zdołał już osobiście przygotować do druku, można wywnioskować, że także jego wyobrażenia eschatologiczne tchną nieśmiałym optymizmem. Skonstatował tam: „Nic nie jest stracone $\mathrm{z}$ tego, co było. W znaczeniu minimalnym: nic nie będzie mogło wymazać istnienia, które było"38. Podobną myśl można znaleźć w urywku Notatnika: Bon nad Lemanem Miłosza: „I nie ustaje pamięć ni dążenie”, które jednak, należałoby $\mathrm{w}$ pierwszym rzędzie uznać za rekapitulację motywów zaczerpniętych z Prophetic Books Williama Blake'a:

$$
\begin{aligned}
& \text {... ani jedna Chwila } \\
& \text { Czasu nie ginie, ani jedno Zdarzenie w Przestrzeni. } \\
& \text { Wszystko zostaje: cała tkanina Sześciu Tysięcy Lat } \\
& \text { Trwa, tak jak trwała... }
\end{aligned}
$$

Trwanie przeszłości, nawet „blask na wodach czarnej rzeki”, gdzie motyw „czarnych wód” będący akwatyczną ilustracją Lesmosyne, bóstwa niepamięci, antytezy Mnemosyne, przemieni ostatecznie w boskie i wieczne światło. Letejskie nurty zostaną opromienione i przeniknięte światłem pierwszej z boginek ${ }^{40}$. Oczywiście są to kolejne próby zaadaptowania „teorii transmutacji” Oskara Miłosza, dalekiego krewnego z Francji, do własnej poezji przez autora Jasności promienistych. Nietrwałe ziemskie lux brevis zostaje $\mathrm{w}$ tej koncepcji przekształcone $\mathrm{w}$ perpetua brevis, a ta-

${ }^{37}$ Por. wagę szczegółu naprowadzającego pamięć na zapamiętaną osobę w utworach polskiego noblisty, m.in. w utworach: Krawat Aleksandra Wata, Suknia w groszki.

38 P. Ricoeur, Żyć aż do śmierci oraz fragmenty, przeł. A. Turczyn, Universitas, Kraków 2008, s. 82.

${ }^{39}$ Cyt. za: K. Van Hauckelom, „Patrzeć w promień...”, dz. cyt., s. 99.

40 Tamże, s. 77. 
jemnicze „Słońce Pamięci” (dosł. Soleil de la Memoire), prześwietlające ludzki byt, miałoby czynić egzystencję człowieka znośniejszą, w tym otwarciu przed nią perspektyw wieczności.

\section{Całość i czesść}

Walor upamiętnienia wysuwa się na dominujacy plan także w utworach polskiego noblisty poświęconych przodkom. Retrospektywny odbiór osobistej przeszłości byłby przecież rażąco niepełny bez choćby próby dotarcia do pokładów osobistej genealogii. Toteż pisarz mierzył się z rodzinną historią wiele razy, na przykład w na poły autobiograficznej Dolinie Issy (1953) czy w Rodzinnej Europie (1958). W drugiej z nich autobiografia intelektualisty rozpoczyna się deklaracją: „Zaczynam eksplorację, wyprawę w głąb własnej, jednak nie tylko własnej, przeszłości" (RE, 7). Równie poczesne miejsce tematyka związków familijnych zajmuje w późnych zbiorach wierszy, pisanych z perspektywy „podliczenia” elegijnego bilansu życia ${ }^{41}$. W kolistych nawrotach wspomnien Miłosz rekonstruuje życie męskich poprzedników z linii Kunatów (Mój dziadek Zygmunt Kunat) i Syruciów (Pan Syruć), akcentując, że jego celem jest uwiecznienie zwyczajnych ludzi, istnienie których najczęściej przemilczają historyczne annały:

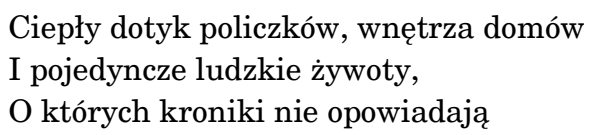

(W4, 228).

To, co oficjalne kroniki pomijają, indywidualna intymistyka nierzadko przechowała w postaci wiedzy o lokalnych bohaterach codzienności żyjących blisko, po sąsiedzku. W Przypisie po latach, dołączonym do wydania Doliny Issy w roku 2000, zawarł Czesław Miłosz obszerny fragment pamiętnika Wycieczka nad Niewiaże (1879), autorstwa Jakuba Gieysztora, właściciela majątku Ignacogród, odległego ledwie o parę kilometrów od jego rodzinnych Szetejń. Stamtąd poeta przytoczył następujący obszerny zapis dotyczący osoby pradziadka:

Przed nami obszerna osada, budowle ze wszystkich stron otaczają śliczne drzewa, jakby lasek naturalny - to są Szetejnie. Jednakże, gdym był dzieckiem, pamiętam dobrze, jak na wzgórzu nagiem, ocienionym tylko dwiema wierzbami, kilka lichych budowli wcale oka nie nęciło. Dziś Szetejnie są jedną z najwdzięczniejszych miejscowości, dzięki wytrwałej pracy i gustowi Szymona Syrucia. Jakiż

${ }^{41}$ Motyw ten analizuje Anna Legeżyńska w książce Gest pożegnania. Szkice o poetyckiej świadomości elegijno-ironicznej, Poznańskie Studia Polonistyczne, Poznań 1999. 
to przykład dla naszych ziemian, aby upiększali swe siedziby i czynili je pamiętnemi dla oka: kraj nasz przybierze postać cywilizowaną, a może też własne dzieci i wnuki, korzystając z cienia drzew, z wygodnych zabudowań, pamięć ich błogosławić będą (DI, 6).

Zwróćmy uwagę, że osiemnastowieczny autor, wychwalając przemyślane z dbałością zagospodarowanie naturalnego terenu, mówi tutaj również o czymś w rodzaju „pamięci dla oka”, zastrzegając przy tym, że aby warto było zapamiętać jakiś krajobraz, prócz wychwalanego waloru użyteczności („cien”, „wygodna zabudowa”) wcale nie mniej powinien on odpowiadać estetycznym potrzebom człowieka i być wizualnie atrakcyjny dla patrzącego, aby za pomocą narządu wzroku jako kadr z rzeczywistości mógł być zarejestrowany w ludzkim umyśle. Upiększanie najbliższego otoczenia to powszechna konieczność, a nie luksusowy zbytek. Jednocześnie pozytywistyczne nastawienie pamiętnikarza, widoczne choćby w postulacie "pracy organicznej”, ukierunkowanej na „cywilizowanie” pierwotnego środowiska przyrodniczego, zdaniem Gieysztora, może być skutecznym sposobem na zaskarbienie sobie „błogosławionej pamięci” potomnych. Pogląd ten podzielał i Miłosz, przekonany, iż wypełnianie powszednich i żmudnych obowiązków godne jest ze wszech miar utrwalenia, ponieważ:

... tak być powinno, żebyśmy spełniali życie w drobnej krzątaninie, Starając się być w zgodzie z naszą linią losu

(W5, 263).

Na kanwie dziejów swojego rodu i - może jeszcze bardziej zachowując świadomość, że w czasie historycznym, na jaki przypadła jego jednostkowa biografia, bo już - „wschodził wiek bezdomności” (PP, 161), autor Zniewolonego umysłu przedstawił własne rozumienie pomyślności losu, słyszane w głosie kierowanym do Drugiego:

wiedz, że możesz uważać się za szczęśliwego, jeżeli życie twoje układało się tak jak życie twoich sąsiadów. Jeżeli poruszałeś się, myślałeś, czułeś tak samo jak oni i tak jak oni dopełniałeś tego, co trzeba, w czasie właściwym. Jeżeli rok za rokiem obowiązki i obrzędy następowały po sobie, pojąłeś żonę, wychowałeś dzieci i spokojnie mogłeś spotykać ciemniejące dni starości (PP, 308).

Wobec „nieobjętej ziemi”, jej skomplikowanych spraw oraz złożoności ludzkiego istnienia Miłosz zaleca, aby zająć się tym, co naprawdę ważne, tym, co samemu można kształtować, a w czym on sam widział rdzeń egzystencji człowieka, czyli skromną - ,jako-takość” (W4, 49), której w płaszczyźnie artystycznej odpowiadała koncepcja pokornej sztuki mimesis. 
Z tych osobistych przekonań Starego Poety płyną też nakazy: „pochwalaj przeciętność”, „bądź takim jak inni” (PP, 308), które powielają w pewnym stopniu szlachecki kanon zachowań, proponujący wszak przed wiekami dążenie do osiągnięcia „złotego środka” oraz ideał „poprzestawania na małym", i rozumiane jako sedno życia pozostawały tyle zaleceniem, ile miarą szczęśliwej biografii człowieka. Rzec by można, iż stanowią one rodzaj adhortatio, retorycznej zachęty kierowanej przez Miłosza do współczesnych pokoleń i tych, które dopiero mają nadejść. Te same motywy: indywidualnego szczęścia podmiotu, powinności moralnych, doświadczenia napotkamy $\mathrm{w}$ projekcie etyki Ricoeura, wywiedzionym z Arystotelesowskiej phronesis (roztropności), którego osią teleologiczną będzie pojęcie i dążenie w podjętych działaniach do „życia dobrego"42. Francuski fenomenolog, przemodelowując tradycyjne kategorie wartościowania i oceny, dopełni dialektycznie etykę o moralność w sensie sformułowanym przez Immanuela Kanta, utrzymując, iż nie ma „życia dobrego" bez zachowania szacunku dla uniwersalnych norm społecznych. W „przestrzeni autobiograficznej”43 także Miłosz orientował się za pomocą aksjologicznej busoli, nierzadko obierając kurs w literaturze według ustawienia kierunku wskazówek na mikrokosmos Litwy dzieciństwa. Sam, wychowany przecież wśród guseł i wierzeń ludowych ${ }^{44}$, podobnie do narratora autobiograficznej opowieści znad Doliny Issy, chłonący w dzieciństwie barwne przekazy litewskiej społeczności, mógłby chyba podzielać stanowisko z gruntu obcych mu psychoanalityków, w tym jednym i zarazem jedynym punkcie ich teorii:

wedle którego głos przodków nadal daje się słyszeć między żywymi i zapewnia w ten sposób nie tylko przekazywanie mądrości, lecz także jej wewnętrzne przyjmowanie na każdym etapie. Wymiar ten, który można nazwać pokoleniowym [wyr. - P.R.], jest niezaprzeczalnym składnikiem nakazu, a jeszcze bardziej - długu $^{45}$.

42 Zob. P. Ricoeur, Dążenie do życia dobrego, w: tegoż, O sobie samym jako innym, dz. cyt., s. 284-298.

43 Termin Philippe'a Lejeune'a. Wedle pomysłodawcy jest on szczególnie dogodny w przypadku całościowego interpretowania spuścizny danego autora, ponieważ obejmuje swym zakresem ogół pozostałych po nim dzieł (fikcjonalnych oraz intymnych), sprawiając, że mogą się one nawzajem dopełniać, tworząc spójny wizerunek pisarza. Zob. część Pakt autobiograficzny, w: Ph. Lejeune, Wariacje na temat pewnego paktu. O autobiografii, red. R. Lubas-Bartoszyńska, przeł. W. Grajewski, S. Jaworski, A. Labuda, R. Lubas-Bartoszyńska, Universitas, Kraków 2001.

44 Zob. charakterystykę czasoprzestrzennej topografii doliny Issy w rozpoczęciu powieści Czesława Miłosza, Dolina Issy.

${ }^{45}$ P. Ricoeur, O sobie samy jako innym, dz. cyt., s. 588. 
Paul Ricoeur na zakończenie rozważań $O$ sobie samym jako innym wybrał analizę zjawiska, które nazwał „pokoleniowym modelem sumienia”, a które znajduje odzwierciedlenie w memorialnej twórczości polskiego poety. Francuski filozof akcentuje antropologiczny wymiar „metapsychologii" Zygmunta Freuda dochodzący do głosu w warstwie superego, czyli sumienia, gdzie zostają skrystalizowane przekonania autorytetów - rodziców i przodków wraz z kultywowanymi przez nich wartościami. Tym samym „inność” w sobie, po odkrytej wcześniej przez podmiot obcości ciała oraz Innego, zyskuje trzeci wymiar, upostaciowana w nieredukowalnej instancji „sumienia”46.

Ostatecznie, koncepcja podmiotu nostalgicznej poezji Miłosza wykazuje więc wiele punktów przecięcia z kategorią poświadczenia Ricoeura. Wspólne są w nich obu: pojęcie „długu” zapośredniczonego przez współczesnych od minionych pokoleń, nakaz pielęgnowania pamięci o przodkach jako forma moralnej spłaty, a ponadto w „planie życia” moralne dążenie do osiągnięcia „życia dobrego”. W ocenie autora Ziemi Ulro właśnie hołdowanie przekonaniom etycznym nadało sens jego istnieniu, bo jak stwierdził: [był] „więc człowiekiem, który tak się urządza, żeby wierzyć $\mathrm{w}$ metafizyczne powody swego istnienia, czyli w to, że jeżeli żyje, to został zawczasu do czegoś powołany" (ZU, 202). Po wtóre, zachowanie śladów minionego istnienia, sam Ricoeur określił swoją egzystencję przez pryzmat tropu odciśniętego przez obecność Jacques'a Derridy w jego życiu, zakłada jako hipotezę trwanie przeszłości w planie biografii tego, kto nas przeżyje - zgodnie ze spekulatywnym przypuszczeniem umysłu, że: „Jednak istnieje ślad innych, do którego i mój się dołączy, podług swojej miary"47. Tym samym pojęcie śladu mnezyjnego zostaje radykalnie rozszerzone, przekraczając granice Ja i odtąd - jak powiada myśliciel „przechodzi przez moich bliskich” 48 .

Otóż korowód żyjących, jeszcze wraz z „tymi, co kiedyś żyli” (W5, 296), ujrzy znów Miłosz w imaginatywnej wizji, stojąc przed obrazem Hieronima Boscha Ogród ziemskich rozkoszy w muzeum Prado, by potem nadać cyklowi sześciu swoich wierszy identyczny tytuł, tyle że zaopatrzony w dodatkowy cudzysłów. Żaden z napisanych liryków nie jest jednak, co można by wywnioskować z niejako „narzucającej się” poprzez kontekst „sytuacji lirycznej”, ekfrazą. Dzieła malarskiego mistrza sprzed wieków potrzebował będzie poeta tylko pretekstowo, w formie poręcznej rekwizytorni, z której można łatwo wydobyć upragnioną rzecz. Miłosz sięga do pamięci po dobrze zapamiętywany motyw z obrazu Boscha (funkcjonujący

46 Tamże, s. 591.

47 P. Ricoeur, Żyć à̇ do śmierci..., dz. cyt., s. 135.

48 Tamże. 
w świadomości odbiorców sztuki na zasadzie „synonimu” albo metonimii tego dzieła plastycznego), czyli ludzkiej postaci otoczonej w pęcherzyku powietrza: „Dzieje się to w środku przezroczystej kuli” (W4, 9). Poeta identyfikuje się $\mathrm{z}$ tak przedstawioną na obrazie postacią, rozpoznając $\mathrm{w}$ niej swoją osobę, podobnie jak wcześniej (w rzeczywistości świata przedstawionego) zobaczył siebie w bryłce słonecznego kamienia: „będę zamknięty jak mucha w bursztynie” (W4, 9). Co łączy obie wyobrażone postaci: tę, otoczoną bańką eteru $\mathrm{z}$ tamtą, zatopioną w minerale? - Obie one pozwalają ujrzeć ziemską egzystencję w doskonałych proporcjach idealnej kuli, w centrum której umieszczone podmiotowe Ja, wędrując po okręgu rozumienia interpretuje siebie i sobie podobne istoty. Przecież Charles Taylor zdefiniował kiedyś człowieka jako self-interpreting animal $^{49}$. W refleksji Ricoeura motyw ten znajduje eksplikację o charakterze moralnym:

Tak więc żywych i umarłych łączy jedyna w swoim rodzaju pietas. Pietas ta odzwierciedla koło, w którym ostatecznie się obracamy: skąd przodek czerpie powagę swojego głosu, jeśli nie ze swej domniemanej wyróżnionej więzi z Prawem, jak on niepamiętnym? W ten sposób nakaz poprzedza sam siebie za pośrednictwem przodka, pokoleniowej postaci Innego ${ }^{50}$.

Podobne znaczenia Jolanta Dudek nadaje symbolowi bursztynu w poezji Miłosza, widząc jednak tę rzecz bardziej wieloznacznie:

Owa bryłka płonącego kamienia z Laudy (tj. kamienia słonecznego, symbolu inspiracji poetyckiej i „materii duchowej”, świętego kamienia Litwinów, symbolu, miłości i wierności, utożsamionego $\mathrm{w}$ micie greckim ze skamieniałymi łzami wygnanego z Olimpu Apolla) jest też symbolem wyemanowanej przez autora Laudy duchowej ojczyzny odkupionej, która jest zarazem podobnie jak u ks. Skargi i Mickiewicza prefiguracją Jeruzalem niebiańskiej lub „miejsca miejsc” O.V. Miłosza ${ }^{51}$.

$\mathrm{Na}$ zakończenie rozważań o holograficznym modelu nostalgii w poezji autora Dalszych okolic proponuję przyjrzeć się trzem przykładom z prozy dwudziestowiecznej o charakterze intymnym. Motyw kuli funkcjonuje w autobiograficznym pisarstwie Vladimira Nabokova i Czesława Miłosza jako rodzaj przestrzennej metafory, która służyła każdemu z nich do bui nast.

49 Motyw ten rozwija Ricoeur w dziele $O$ sobie samym jako innym, dz. cyt., s. 297

50 Tegoż, Żyć à̇ do śmierci..., dz. cyt., s. 589.

51 J. Dudek, Europejskie korzenie poezji Czesława Miłosza, Księgarnia Akademicka, Kraków 1995, s. 87. 
dowania literackiego modelu ziemskiego losu człowieka z jego metafizycznym przedłużeniem w czasie.

\section{Vladimir Nabokov:}

Spirala to spirytualne koło. Koło $\mathrm{w}$ formie spirali, nieskręcone, niezamknięte przestaje być błędne; oswobodziło się. Wymyśliłem to jeszcze w szkole, kiedy również odkryłem, że Heglowska triada (tak popularna w dawnej Rosji) wyraża jedynie zasadniczą spiralność wszechrzeczy w odniesieniu do czasu. Zwój następuje po zwoju, a każda synteza stanowi tezę kolejnego ciągu. Jeżeli wziąć najprostszą spiralę, można w niej wyróżnić trzy fazy odpowiadające fazom triady [... - A.R.]. Kolorowa spirala w szklanej kulce - tak widzę swoje życie [wyr. - A.R.] ${ }^{52}$.

\section{Czesław Miłosz:}

W południe sekretarka gasi komputer i idzie na lunch, a w niej cała ludzkość dotychczasowa krąży, wiruje, jak przezroczyste linie w kuli [wyr. A.R.]. Właśnie to, odbicie w niej jednej tysiącleci ludzkich, bogów, demonów, wiar, obrzędów, wyroków, zwyczajów, całopaleń, eposów jest trudne do pojęcia. [... - A.R.] A zarazem nie jest tylko bąbelkiem powietrza na wielkiej fali, także istnieje jako ona, i to jest chyba najbardziej zagadkowe (PP, 225).

\section{Czesław Miłosz:}

Istnieją stare filozoficzne pomysły Greków, że jedność jest dobrem, a wielość jest złem. Że jedność ogólnie jest dobrem. Dlatego na przykład koło jest najbardziej doskonałą figurą geometryczną, bo jest zamknięte. Kula jest dobra, bo jest w sobie zamknięta, bo jest jednością. A że człowiek jest jakby drzazgą odszczepioną od tej kuli, jest indywidualnym istnieniem, to musi za to zapłacić, że jest oddzielony od tej jedności [wyr. - A.R.]. To co dzie$l i$, upada - śmierć, zapomnienie jest niby karą za tą indywidualność, że jest się oddzielonym. Mój krzyk jest protestem przeciwko temu przemijaniu i zanikaniu, dlatego że jestem oddzielony. I mówię: Tylko to co dzieli nie upada, czyli na odwrót. Dlatego że wszystko inne jest poza trwaniem. Trwa się w czasie, dlatego że jest się osobną istotą. Nie jest się $\mathrm{w}$ jedności, tylko jest się osobno - i tylko to jest trwanie. Wszystko inne, jakaś doskonała jedność, byłoby poza trwaniem (PŚ, 153).

Linearny bieg życia ma to do siebie, że zarówno jego początek, jak i koniec niknie w mrokach amnezji. Miał tę świadomość Vladimir Nabokov, kiedy tworzył własną autobiografię, lecz dla swoich „kłopotów z istnieniem" wynalazł odkrywczą formułę, wpisując osobiste losy w figurę koła, o brzegach wymodelowanych w wymyślne spiralne kształty, a następnie umieszczając ów wytwór wyobraźni w przezroczystej kuli. Łuki

52 V. Nabokov, Pamięci, przemów. Autobiografia raz jeszcze, przeł. z angielskiego A. Kołyszko, posłowiem opatrzył L. Engelking, MUZA SA, Warszawa 2004, s. 247. 
tej osobliwej spirali odpowiadały zakrętom życiowym, zza których wyłaniał się nowy projekt egzystencji po rewolucji w Rosji: lata wygnania w Europie oraz osiedlenie się w Stanach Zjednoczonych.

Zauważmy, że w urywku z eseju polskiego noblisty spotykamy niemalże identyczną co u Nabokova definicję egzystencji człowieka, ujętą $\mathrm{w}$ formę linii wirującej w zamknięciu, w wirtualnych „przestworzach" kuli na ekranie komputera. Jednocześnie ten obraz tchnie jakąś tajemnicą, właśnie w owej wizualizacji „żywotów” pojedynczych ludzi, odbijających się w lustrzanych ścianach idealnej bryły. Przy tej sposobności Miłosz akcentuje trud podmiotowego stawania się, a posługując się językiem Ricoeura - wznoszenia konstrukcji „sobości” przez Ja - bo podjęcie działań tożsamościowych zostaje przeciwstawione projektowi bezrefleksyjnego życia, oddanego w obrazie biernego unoszenia się „na wielkiej fali” zdarzeń biograficznych. Z kolei wypowiedź „podróżnego świata” z wywiadu udzielonego Renacie Gorczyńskiej wykazuje pozorną sprzeczność $\mathrm{z}$ dopiero co poczynionymi ustaleniami. Poeta manifestuje $\mathrm{w}$ niej nieufność do wszelkich projektów, które konkretną biografię włączają do zbiorowego losu ogółu. Był to również główny powód jego niechęci do nauki Kościoła, gdyż uważał, że to, co wewnętrznie sprzeczne w egzystencji istoty ludzkiej: „nie może być wyrażone w języku teologii, która od wielu stuleci zaokrągla odpowiedzi w gładkie kule, łatwe do toczenia, ale jakby nieprzenikalne" (PP, 35). Lecz, powiada też Miłosz, że człowiek, będący zaledwie „odpryskiem” od całości, funkcjonując poza nią, odbiera swoje życie jako niepełne i przeciw temu buntuje się gwałtownie.

Jednak dobrodziejstwo Mnemosyne pozwala, by poprzez pamięć dotrzeć do rozumienia siebie samego. Zachodzi tutaj rodzaj hermeneutycznej wymiany między częścią, którą stanowi indywidualna biografia, a całością, ilustrowaną przez dzieje bliskich przodków. Przeprowadzanie tego typu „okrężnej analizy” pozwala Ja odzyskać upragniony sens, konieczny do tego, by swoje istnienie uznać za rzeczywiste. Holografia pozwala objąć tę całość i odtwarzać doświadczenie egzystencji oraz memorii $\mathrm{w}$ poetyckiej reprezentacji.

Tak więc Czesław Miłosz układający u schyłku życia własny Traktat teologiczny mógł stwierdzić:

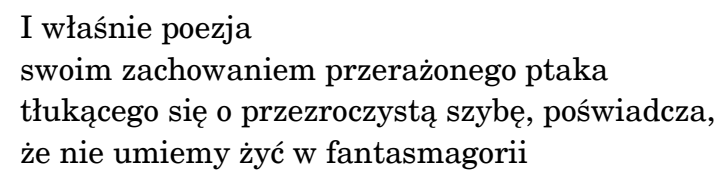

(W5, 218).

Silne jest więc przekonanie poety, że jedynie tworzenie artefaktów stanowi skuteczną obronę przed dehumanizacją, bo nieodmiennie prowo- 
kuje te działania: „Nienazwana potrzeba ładu, rytmu, formy, które to trzy słowa obracamy przeciwko chaosowi i nicości” (W4, 139). Mamy trzy słowa poety przeciw dwóm wyrazom pochodzącym z atroficznej, lecz miażdżącej rzeczywistości. „Pamiętam, więc istnieję”. „Pamiętam, więc to jest egzystencjalny dowód, że ciągle jeszcze żyję". Autor Światta dziennego zdaje się powtarzać takie formuły "filozoficznych” zaklęć osobistych, a jego rozległa i wielogatunkowa twórczość, afirmująca pamięć z wyobraźnią jako formy negacji czasu nihilizującego doświadczenie ludzkiego bytu, opiera się zapomnieniu, na jakie nigdy nie wyrażał zgody, będąc świadomym swego posłannictwa artystą. 